\title{
Digestibility of nutrients and energy of cultivars of forage palm for growing Nile tilapia
}

\section{Digestibilidade de nutrientes e energia de variedades de palma forrageira para tilápia do Nilo em crescimento}

\author{
Marta Sales Oliveira ${ }^{1}$; Kauana Santos Lima²; Filipe dos Santos Cipriano ${ }^{3}$; \\ William Cristiane Teles Tonini' ${ }^{4}$; Rafael Vieira de Azevedo ${ }^{5}$; \\ Ana Lúcia Salaro ${ }^{6}$; Luis Gustavo Tavares Braga ${ }^{7 *}$
}

\begin{abstract}
The objective was to evaluate the apparent digestibility coefficients of nutrients and energy of five cultivars of forage palm (orelha de onça, miúda, gigante, IPA 20 and comum) for growing Nile tilapia $(110.02 \pm 16.17 \mathrm{~g})$. The study design was completely randomized with five treatments, three replicates of eight fish per experimental unit. The diets were composed of $300 \mathrm{~g} / \mathrm{kg}$ of each cultivar of the palm and $700 \mathrm{~g} / \mathrm{kg}$ of the basal diet. Masculinized fish were distributed in circular feed tanks (150 L) and kept in closed circulation of water and constant aeration. The digestibility was estimated by indirect method, using $1.0 \mathrm{~g} / \mathrm{kg}$ chromic oxide as an indicator of the diet and the feces was collected the day after the last feed in digestibility aquariums. The cultivars comum and onça presented the best values for dry matter digestibility $(53.5 \%)$. The lowest value for crude protein digestibility was obtained to cultivar gigante $(60 \%)$ and all cultivars tested showed gross energy digestibility below $50 \%$. Nile tilapia has limitation on the digestibility of dry matter, gross energy, crude protein and amino acids of the cultivars of forage palm IPA 20, miúda, gigante, comum and orelha de onça.

Key words: Alternative feed, aquaculture, nutritional value, Opuntia sp., Oreochromis niloticus, performance
\end{abstract}

\section{Resumo}

Objetivou-se avaliar os coeficientes de digestibilidade aparente de nutrientes e energia de cinco variedades de farelos de palma forrageira (orelha de onça, miúda, gigante, IPA 20 and comum) para tilápia do Nilo em crescimento $(110,02 \pm 16,17 \mathrm{~g})$. As tilápias, masculinizadas, foram distribuídas em tanques circulares de alimentação $(150 \mathrm{~L})$, mantidos em circulação fechada de água e aeração constante. Foi montado um delineamento inteiramente casualizado, composto por cinco tratamentos,

${ }^{1}$ Discente de Mestrado do Programa de Pós-graduação em Ciência Animal, Universidade Estadual de Santa Cruz, UESC, Ilhéus, BA. E-mail: martaadi@hotmal.com

${ }^{2}$ Discente de Doutorado do Programa de Pós-graduação em Zootecnia, Universidade Federal da Bahia, Salvador, UFBA, BA. E-mail: kauana_slima@hotmail.com

${ }^{3}$ Discente de Doutorado do Programa de Pós-graduação em Zootecnia, Universidade Federal de Minas Gerais, UFMG, Minas Gerais, MG. E-mail: filipecipriano@hotmail.com

${ }^{4}$ Prof. da Universidade do Estado da Bahia, UNEB, Xique-Xique, BA. E-mail: willcttonini@gmail.com

${ }^{5}$ Incaper - Instituto Capixaba de Pesquisa, Assistência Técnica e Extensão Rural. Doutorando do Programa de Pós-graduação em Ciência Animal, Universidade Estadual do Norte Fluminense Darcy Ribeiro, Campos dos Goytacazes, RJ. E-mail:azevedorv84@ gmail.com

${ }^{6}$ Prof $^{a}$ do Dept ${ }^{\circ}$ de Biologia Animal, Universidade Federal de Viçosa, Viçosa, MG. E-mail: salaro@ufv.br

${ }^{7}$ Prof. do Laboratório de Nutrição e Alimentação de Peixes, Universidade Estadual de Santa Cruz, UESC, Ilhéus, BA. E-mail: lgtbraga@gmail.com

* Author for correspondence 
três repetições e oito peixes por unidade experimental. As rações teste foram compostas de $30 \%$ de cada cultivar da palma e $70 \%$ da ração referência. A digestibilidade foi estimada pelo método indireto, utilizando-se óxido crômico a $0,1 \%$ da ração como indicador, efetuando-se a coleta de fezes no dia posterior a última alimentação em aquários de digestibilidade. A cultivares orelha de onça e comum apresentaram os melhores valores para a digestibilidade matéria seca $(53,5 \%)$. O menor valor para digestibilidade da proteína bruta foi obtido para cultivar gigante $(60 \%)$ e todas as cultivares testadas apresentaram coeficiente de digestibilidade energia bruta inferior a 50\%. A tilápia-do-nilo apresenta limitação quanto à digestibilidade da matéria seca, energia bruta, proteína bruta e aminoácidos das cultivares IPA 20, miúda, gigante, comum e orelha de onça.

Palavras-chave: Alimento alternativo, aquicultura, Opuntia sp., Oreochromis niloticus, Nopallea sp., valor nutritivo

\section{Introduction}

The production of tilapia in Brazil in 2010 was 155.5 tons (MPA, 2012) and the global production is estimated to increase to about 8.9 million tones by the year 2020 (TACON; METIAN, 2008). This rapid rise is due in part to the increasing intensification of farming systems that take advantage of the positive characteristics of the species such as resistance to high temperatures, low concentrations of dissolved oxygen and high concentration of ammonia in water, easy to obtain larvae, beyond its organoleptic properties (MEURER et al., 2002; JUSTI et al., 2005; SILVA et al., 2006). That makes it a good choice for the semi-intensive and intensive growout strategies. Subsequently, the improving of a practical diet for Nile tilapia is necessary (AHMAD; ABDEL-TAWWAB, 2011)

Fish production costs in the intensive system may exceed 50\% (GUIMARÃES; PEZZATO; BARROS, 2008). In this sense, agriculture by-products represent a viable alternative from the nutritional and economical points of view, and may lower total costs of fish production. One of the attempts to reduce feed costs includes the use of alternative ingredients with good availability and attractive pricing on the market. For this reason, researches have been developed for evaluating the digestibility of different by-products for Nile tilapia (SANTOS et al., 2010; BRAGA et al., 2010; SANTOS et al., 2009; CAVALHEIRO; SOUZA; BORA, 2007; KÖPRÜCÜ; ÖZDEMIR, 2005; PEZZATO, et al., 2004; RICHTER; SIDDHURAJU; BECKER, 2003).
One of the feedstuff with potential use in aquaculture is the palm bran, which belongs to the Cactaceae family and the genus Opuntia and Nopallea. The palm bran stands out for its use in animal feed, especially in arid and semi-arid environments due to their characteristics such as resistance to the rigors of climate and prolonged droughts, and its nutritional characteristics. However there is limited information about the nutritional value of palm bran to farmed fish.

Confined fish need food in sufficient quantity and quality for appropriate reproductive and productive performance, without damage to the environment (FURUYA et al., 2010; BOMFIM et al., 2008). Thus it is important to know the nutrients digestibility in formulating feeds (FURUYA et al., 2001). Also, according to Kleemann, Barros and Pezzato (2009), crude protein digestibility coefficients do not reflect most amino acids digestibility coefficients. Thus, for a more precise and economic formulation of feeds, digestible amino acids values must be used.

In this context, the aim of this study was to assess the digestibility of dry matter, crude protein, gross energy and amino acids of five cultivars of forage palm (orelha de onça, miúda, gigante, comum and IPA 20) for growing Nile tilapia.

\section{Material and Methods}

The experiment was carried out at the Laboratory of Fish Nutrition and Feeding (Aquanut), of Universidade Estadual de Santa Cruz-UESC 
$\left(14^{\circ} 47^{\prime} 50^{\prime \prime} \mathrm{S}, 39^{\circ} 2^{\prime} 8^{\prime \prime} \mathrm{W}\right)$, from January through February, 2011. The study design was completely randomized with five treatments and three replicates to evaluate the digestibility of the following cultivars of forage palm: orelha de onça, miúda, gigante, IPA 20 and comum. Samples of palm cultivars after harvest, were cut to pieces of $5 \mathrm{~cm}$ and dried under forced ventilation $\left(55^{\circ} \mathrm{C}\right)$ for 72 hours. After, the samples were ground in mills knife using a $1 \mathrm{~mm}$ sieve mesh.

A group of 48 masculinized specimens of Nile tilapia (Oreochromis niloticus) with mean weight of $110.02 \pm 16.17 \mathrm{~g}$, was provided by Aguavale Farm, Ituberá, Bahia, Brazil. The physical structure was made up of cages $(60 \mathrm{~L})$ installed in feeding tanks $(150 \mathrm{~L})$, supplied in continuous flow $\left(0.084 \mathrm{~m}^{3} / \mathrm{h}\right)$ of water in a closed circulation system with biological filtration, through constant aeration (aerator Mod. CV-101R, VENTBRAS Ind. Eletrometalúrgica Ltda, SP, BR) and controlled photoperiod (12 h of light). The fish remained in the $150 \mathrm{~L}$ feeding tanks during the adaptation period for each experimental diet (four days) and were fed three times a day. Residues were siphoned off during this period every day. The 200-L digestibility aquariums, conicalbottomed tanks, equipped with a valve and glass collector $(100 \mathrm{~mL})$ dip in a polystyrene box with ice were used as proposed by Portz and Cyrino (2004), to collect fish faeces.

The physic-chemical variables of water $-\mathrm{pH}$ (7.0 \pm 0.1$)$, temperature $\left(26.8 \pm 0.43^{\circ} \mathrm{C}\right)$ and dissolved oxygen $(7.2 \pm 1.43 \mathrm{mg} / \mathrm{L})$ - were monitored daily during the whole experimental period by means of multi-parameter digital equipment (YSY model6310FT and YSY model55-12FT, YSI Corporation, Owings Mills, MA, USA).

The feeds were prepared by the computer program SUPER CRAC ${ }^{\circledR}$ (Viçosa, MG, BR), from the apparent digestibility coefficient values of ingredients used obtained for Nile tilapia, according to Furuya et al. (2010), beyond to cultivars of forage palm evaluated. Indirect method with partial collection of fish feces was used, and test feeds were prepared with the bran made from each palm cultivar, added to the reference feed in the proportion of $300 \mathrm{~g} / \mathrm{kg}$ (Table 3). To determine the apparent digestibility coefficients, $1.0 \mathrm{~g} / \mathrm{kg}$ of chromium oxide $\left(\mathrm{Cr}_{2} \mathrm{O}_{3}\right)$ indicator was added to reference and test feeds, according to Nose (1966).

For the manufacture of animal feed, the ingredients were ground with knife grinder with 0.5 $\mathrm{mm}$ sieve, being later homogenized in accordance with the wording of each feed. Following to that soybean oil and water at $40^{\circ} \mathrm{C}$ were added to moisten the mixture. The feeds were then granulated in pellet mill with frequency inverter ( $3 \mathrm{~mm}$ matrix) and dried in an oven with forced $\operatorname{air}\left(55^{\circ} \mathrm{C}\right)$ for $24 \mathrm{~h}$.

After adaptation period, fish were fed with the test diets at five daily meals. Fish were transferred to the digestibility aquaria (200 L) 20 minutes after the last meal, where they remained overnight. Feces were collected the following morning (7:00 a.m.). One sample of feces from each aquarium was composed of a set of four collections series performed individually. The excess water in the collectors was eliminated and the remaining material was dried under forced ventilation $\left(55^{\circ} \mathrm{C}\right)$ for 36 hours. The removal of the scales with the aid of tweezers and a $0.5 \mathrm{~mm}$ sieve was performed and the material was stored at a freezer $\left(-10^{\circ} \mathrm{C}\right)$, until the chemical analyses were performed.

Crude protein, gross energy and dry matter analyses of experimental feeds and fish excreta were conducted at Laboratory of Animal Nutrition and Aquanut of UESC, according to AOAC (2000) (Table 1). Analyses of forage palm bran amino acids (Table 2), experimental feeds and fish excreta was carried out at the laboratory of Ajinomoto do Brasil Indústria e Comércio de Alimentos Ltda, using HPLC - High Performance Liquid Chromatography. 
Table 3. Formulation and chemical composition of reference diet (in the natural matter).

\begin{tabular}{lc}
\hline Ingredient & $(\mathrm{g} / \mathrm{kg})$ \\
\hline Soybean meal & 290.0 \\
Fish meal & 215.8 \\
Wheat meal & 210.0 \\
Corn starch & 138.1 \\
Corn & 127.4 \\
Vitamin and mineral premix ${ }^{1}$ & 10.0 \\
Soybean oil & 8.5 \\
BHT $^{2}$ & 0.2 \\
Chromium oxide III $^{\text {Ingredient test }}$ & 1.0 \\
Calculated value & 0.0 \\
Crude protein & $(\mathrm{g} / \mathrm{kg})$ \\
Digestible protein & 290.7 \\
Digestible energy $(\mathrm{Kcal} / \mathrm{Kg})$ & 260.0 \\
Fat & 3004 \\
Crude fiber & 40.4 \\
\hline
\end{tabular}

${ }^{1}$ Vitamin and mineral premix. Guarantee level per kg of product: vit. A $=6,000,000 \mathrm{UI}$; vit. D3 $=2,250,000 \mathrm{UI}$; vit. $\mathrm{E}=75,000$ $\mathrm{mg}$; vit. $\mathrm{K} 3=3,000 \mathrm{mg}$; vit. thiamin $=5,000 \mathrm{mg}$; riboflavin $=10,000 \mathrm{mg}$; vit. pyrodoxin $=8.000 \mathrm{mg}$; biotin = 2,000 $\mathrm{mg}$; vit. $\mathrm{C}=$ 192,500 mg; niacin = 30,000 mg; folic acid = 3,000 mg; Fe = 100,000 mg; $\mathrm{Cu}=600 \mathrm{mg} ; \mathrm{Mn}=60,000 \mathrm{mg} ; \mathrm{Zn}=150,000 \mathrm{mg} ; \mathrm{I}=$ $4,500 \mathrm{mg} ; \mathrm{Co}=2,000 \mathrm{mg} ; \mathrm{Se}=400 \mathrm{mg}$

${ }^{2} \mathrm{BHT}=$ Butylated hydroxytoluene

Source: Elaboration of the authors.

Table 1. Composition of the cultivars of forage palm bran offered (in the natural matter).

\begin{tabular}{lccccc}
\hline \multicolumn{1}{c}{ Cultivar } & Dry matter $(\%)$ & $\begin{array}{c}\text { Gross energy } \\
(\mathrm{kcal} / \mathrm{kg})\end{array}$ & $\begin{array}{c}\text { Crude protein } \\
(\%)\end{array}$ & $\begin{array}{c}\mathrm{NDF}^{1} \\
(\%)\end{array}$ & $\begin{array}{c}\mathrm{ADF}^{2} \\
(\%)\end{array}$ \\
\hline Orelha de onça & 88.33 & 2,84 & 6.99 & 39.78 & 19.26 \\
Miúda & 89.22 & 3,03 & 12.71 & 30.61 & 11.03 \\
Gigante & 88.82 & 3,36 & 6.07 & 39.01 & 18.75 \\
IPA 20 & 88.33 & 3,28 & 10.05 & 41.77 & 19.63 \\
Comum & 88.77 & 3,42 & 7.09 & 42.96 & 22.13 \\
\hline
\end{tabular}

${ }^{1}$ Neutral detergent fiber

${ }^{2}$ Acid detergent fiber

Source: Elaboration of the authors. 
Table 2. Amino acid compositions $(\mathrm{g} / 100 \mathrm{~g})$ of the cultivars of forage palm bran (in the natural matter).

\begin{tabular}{lccccc}
\hline \multirow{2}{*}{ Amino acid } & \multicolumn{5}{c}{ Cultivar of forage palm } \\
\cline { 2 - 5 } & Orelha de onça & Miúda & Gigante & IPA 20 & Comum \\
\hline Alanine & 0.329 & 0.962 & 0.288 & 0.401 & 0.316 \\
Arginine & 0.238 & 1.167 & 0.239 & 0.410 & 0.114 \\
Asparagine & 0.568 & 1.647 & 0.485 & 0.715 & 0.548 \\
Cystine & 0.100 & 0.298 & 0.082 & 0.139 & 0.100 \\
Glutamine & 0.765 & 2.494 & 0.665 & 0.913 & 0.775 \\
Glycine & 0.304 & 1.225 & 0.261 & 0.354 & 0.260 \\
Histidine & 0.095 & 0.397 & 0.093 & 0.190 & 0.099 \\
Isoleucine & 0.253 & 0.684 & 0.220 & 0.344 & 0.240 \\
Leucine & 0.450 & 1.294 & 0.401 & 0.617 & 0.436 \\
Lysine & 0.301 & 0.921 & 0.254 & 0.427 & 0.285 \\
Methionine & 0.088 & 0.352 & 0.145 & 0.139 & 0.076 \\
Phenylalanine & 0.296 & 0.816 & 0.264 & 0.447 & 0.272 \\
Serine & 0.296 & 0.968 & 0.250 & 0.404 & 0.292 \\
Threonine & 0.268 & 0.712 & 0.226 & 0.365 & 0.267 \\
Tyrosine & 0.177 & 0.516 & 0.155 & 0.282 & 0.154 \\
Valine & 0.331 & 0.847 & 0.281 & 0.395 & 0.313 \\
\hline
\end{tabular}

Source: Elaboration of the authors.

Chromium oxide content in feeds and excreta were determined by atomic absorption at Laboratory of Animal Nutrition of EMBRAPA, Dourados, Mato Grosso do Sul, Brazil. The apparent digestibility coefficients (ADC) were calculated according to Köprücü and Özdemir (2005):

$$
\begin{aligned}
& \mathrm{ADC}=100 \times[1-(\mathrm{F} / \mathrm{D}) \times(\mathrm{Di} / \mathrm{Fi})] \\
& \mathrm{ADC}_{\mathrm{I}}=\left[\mathrm{ADC}_{\mathrm{T}}-\left(0.7 \times \mathrm{ADC}_{\mathrm{R}}\right)\right] / 0.3
\end{aligned}
$$

where: $\mathrm{D}=\%$ nutrient or diet energy; $\mathrm{F}=\%$ nutrient or feces energy; $\mathrm{Di}=\%$ marker $\left(\mathrm{Cr}_{2} \mathrm{O}_{3}\right)$ in the diet; $\mathrm{Fi}=\%$ marker $\left(\mathrm{Cr}_{2} \mathrm{O}_{3}\right)$ in feces, $\mathrm{ADC}_{\mathrm{T}}=$ $\%$ apparent digestibility coefficient of nutrient or energy in the test diet; $\mathrm{ADC}_{\mathrm{R}}=$ apparent digestibility coefficient of nutrient or energy in the reference diet; $\mathrm{I}=$ test ingredient under investigation.

The data obtained were subjected to ANOVA at $5 \%$ of significance level. In case of differences, it was applied the Tukey test by using the PROC MIXED do SAS (Statistical Analysis System, version9.0).

\section{Results and Discussion}

Apparent digestibility coefficients (ADC) of dry matter, crude protein, gross energy and amino acids presented statistical differences $(\mathrm{P}<0.05)$ between the cultivars of forage palm bran studied (Table 4). Cultivars orelha de onça and comum presented similar dry matter ADC and were higher $(\mathrm{P}<0.05)$ than gigante, IPA 20 and miúda. The cultivar gigante, in turn, was higher $(\mathrm{P}<0.05)$ than cultivars IPA 20 and miúda.

Dry matter ADC of some cultivars of palm bran studied (orelha de onça and comum) were higher than those obtained for traditional ingredients used in Nile tilapia feeds, such as corn (52.3\%) and corn starch (48.7\%) (PEZZATO et al., 2002) and wheat bran (45.0\%) (GUIMARÃES; PEZZATO; BARROS, 2008). It was observed that the results observed in this study, when compared to dry matter ADC obtained with alternative products for Nile tilapia, for all palm cultivars studied, were higher than cocoa bran (43.9\%) (BRAGA et al., 2010) and lower than triticale $(70.9 \%)$ (TACHIBANA et al., 2010). 
Table 4. Apparent digestibility coefficients (\%) of the cultivars of forage palm bran for Nile tilapia.

\begin{tabular}{lcccccc}
\hline \multirow{2}{*}{ Parameter } & \multicolumn{9}{c}{ Cultivar of forage palm } & \multirow{2}{*}{ CV $(\%)$} \\
\cline { 2 - 5 } & Orelha de onça & Miúda & Gigante & IPA 20 & Comum & \\
\hline Dry matter & $54.04^{\mathrm{a}}$ & $47.92^{\mathrm{c}}$ & $50.02^{\mathrm{b}}$ & $48.29^{\mathrm{c}}$ & $53.08^{\mathrm{a}}$ & 0.92 \\
Crude protein & $66.63^{\mathrm{ab}}$ & $73.34^{\mathrm{ab}}$ & $60.04^{\mathrm{b}}$ & $75.43^{\mathrm{a}}$ & $78.21^{\mathrm{a}}$ & 7.21 \\
Gross energy & $49.65^{\mathrm{a}}$ & $45.46^{\mathrm{ab}}$ & $46.48^{\mathrm{ab}}$ & $43.02^{\mathrm{b}}$ & $47.55^{\mathrm{ab}}$ & 4.96 \\
\hline
\end{tabular}

Means within lines followed by different letters statically differ by Tukey test at $5 \%$ of probability.

Source: Elaboration of the authors.

The variations between dry matter ADC presented between palm cultivars may be due to the presence of tannin. In a study conducted by Cardador-Martínez, Jiménez-Martínez and Sandoval (2011) with cactus pear (Opuntia spp.) wastes was observed that tannins were the major phenolics in cactus pear seeds accounting for almost $50 \%$ for all cultivars. According to Pinto et al. (2000), tannin concentration equal to or higher than $4.6 \mathrm{~g} / \mathrm{kg}$ in feed significantly decreases dry matter ADC in Nile tilapia.

As regards crude protein ADC, cultivars IPA 20 and comum were, on average, $27.9 \%$ higher $(\mathrm{P}<0.05)$ in relation to gigante, but did not differ $(\mathrm{P}>0.05)$ from cultivars orelha de onça and miúda. When compared to the traditional feeds used in the manufacturing of tilapia feed, crude protein ADC for all cultivars found in this study were lower to those evaluated by Pezzato et al. (2002), for energetic sources like a corn (91.6\%) and corn starch (91.9\%) for Nile tilapia. However, when compared to the agro-industrial by-products tested by Braga et al. (2010) for the same species, we verified superiority in relation to the ADC of mesquite pod bran protein (51.6\%), manioc leaves bran (49.8\%) and cocoa bran $(38.5 \%)$. The lower values of crude protein ADC, when compared to traditional ingredients, are possibly due to the presence of tannin that has an inhibiting action on digestive enzymes (PINTO et al., 2000).

As to gross energy ADC, the cultivar orelha de onça was $15.2 \%$ higher $(\mathrm{P}<0.05)$ than IPA 20 and similar $(\mathrm{P}>0.05)$ to the other cultivars, which were similar $(\mathrm{P}>0.05)$ to IPA 20. A possibility to explain the variation between the results is the non-fiber carbohydrate present in cultivars. According to Shiau (1997) the intestinal absorption of carbohydrate is low when diets contain fiber, regardless of source. Meal frequency affects carbohydrate utilization in fish. Some carbohydrate metabolic enzymes are altered due to changes in meal frequency. The use of cultivars evaluated as possible substitutes for energy sources in feed formulation for tilapia must be done with discretion due to the limited ability to digest and absorb the energy fraction.

When compared to the ingredients commonly used for the manufacture of feeds, the gross energy values are lower than those obtained for wheat bran $(91.3 \%)$, corn meal $(83.9 \%)$, and corn starch (77.7\%) by Pezzato et al. (2002) for Nile tilapia. On the other hand, as regards alternative ingredients, values were higher than cotton bran (39.6\%), mesquite pod bran $(30.5 \%)$, manioc leaves bran (29.3\%) and cocoa bran (23.1\%), obtained by Braga et al. (2010) for Nile tilapia, similar to those found by Biudes, Pezzato and Camargo (2009) using water lilies (42.3\%) and lower than those found by Lima et al. (2011), who evaluated mango waste bran (76.9\%), both for Nile tilapia.

In general, differences found in the ADC can be attributed to the high amount of minerals and fiber, such as lignin, cellulose, hemicellulose and pectin, and the tannin present in palm bran. Hilton, Atkinson and Slinger (1983) claimed that the high concentration of fiber in feed can result in lower feed ingestion and reduce digestibility of all 
nutrients present in the feed. Values lower than 50 $\mathrm{g} / \mathrm{kg}$ do not influence crude protein and dry matter ADC (LANNA et al., 2004).

Cultivars that presented the higher $(\mathrm{P}<0.05)$ results of essential and nonessential amino acids ADC were comum, IPA 20 and orelha de onça, in contrast to the cultivar gigante, that presented the worst $(\mathrm{P}<0.05)$ amino acids ADC. Essential and nonessential amino acids ADC were similar $(\mathrm{P}>0.05)$ for the cultivars orelha de onça, IPA 20 and comum, with exception for phenylalanine and tyrosine (Table 5).

Table 5. Apparent digestibility coefficients of amino acids (\%) of the cultivars of forage palm bran for Nile tilapia.

\begin{tabular}{lcccccc}
\hline \multirow{2}{*}{ Amino acid } & \multicolumn{5}{c}{ Cultivar of forage palm } & \multirow{2}{*}{ CV $(\%)$} \\
\cline { 2 - 5 } & Orelha de onça & Miúda & Gigante & IPA 20 & Comum & \\
\hline Alanine & $78.72^{\mathrm{a}}$ & $73.04^{\mathrm{b}}$ & $59.60^{\mathrm{c}}$ & $78.54^{\mathrm{a}}$ & $81.04^{\mathrm{a}}$ & 1.52 \\
Arginine & $85.18^{\mathrm{a}}$ & $86.53^{\mathrm{a}}$ & $65.13^{\mathrm{b}}$ & $87.82^{\mathrm{a}}$ & $87.79^{\mathrm{a}}$ & 1.95 \\
Asparagine & $84.11^{\mathrm{a}}$ & $78.69^{\mathrm{a}}$ & $62.50^{\mathrm{b}}$ & $84.27^{\mathrm{a}}$ & $84.34^{\mathrm{a}}$ & 2.98 \\
Cysteine & $77.45^{\mathrm{a}}$ & $75.54^{\mathrm{a}}$ & $59.12^{\mathrm{b}}$ & $76.23^{\mathrm{a}}$ & $78.03^{\mathrm{a}}$ & 3.02 \\
Glutamine & $86.14^{\mathrm{a}}$ & $82.48^{\mathrm{b}}$ & $64.71^{\mathrm{c}}$ & $85.70^{\mathrm{ab}}$ & $87.24^{\mathrm{a}}$ & 1.53 \\
Glycine & $82.58^{\mathrm{a}}$ & $77.44^{\mathrm{b}}$ & $62.17^{\mathrm{c}}$ & $79.94^{\mathrm{ab}}$ & $83.11^{\mathrm{a}}$ & 1.66 \\
Histidine & $79.91^{\mathrm{a}}$ & $80.02^{\mathrm{a}}$ & $61.10^{\mathrm{b}}$ & $82.54^{\mathrm{a}}$ & $81.39^{\mathrm{a}}$ & 1.89 \\
Isoleucine & $78.03^{\mathrm{a}}$ & $73.77^{\mathrm{b}}$ & $59.73^{\mathrm{c}}$ & $81.03^{\mathrm{a}}$ & $81.03^{\mathrm{a}}$ & 2.06 \\
Leucine & $76.54^{\mathrm{ab}}$ & $73.74^{\mathrm{b}}$ & $60.25^{\mathrm{c}}$ & $79.26^{\mathrm{a}}$ & $79.88^{\mathrm{a}}$ & 1.85 \\
Lysine & $79.69^{\mathrm{a}}$ & $75.73^{\mathrm{b}}$ & $61.08^{\mathrm{c}}$ & $80.41^{\mathrm{a}}$ & $81.71^{\mathrm{a}}$ & 1.42 \\
Methionine & $79.04^{\mathrm{a}}$ & $78.27^{\mathrm{a}}$ & $60.55^{\mathrm{b}}$ & $83.60^{\mathrm{a}}$ & $82.80^{\mathrm{a}}$ & 3.13 \\
Phenylalanine & $74.52^{\mathrm{b}}$ & $74.55^{\mathrm{b}}$ & $59.88^{\mathrm{c}}$ & $79.06^{\mathrm{a}}$ & $79.73^{\mathrm{a}}$ & 1.66 \\
Serine & $84.19^{\mathrm{a}}$ & $79.61^{\mathrm{b}}$ & $62.82^{\mathrm{c}}$ & $82.74^{\mathrm{ab}}$ & $84.19^{\mathrm{a}}$ & 1.81 \\
Threonine & $78.14^{\mathrm{a}}$ & $71.90^{\mathrm{b}}$ & $59.34^{\mathrm{c}}$ & $77.18^{\mathrm{a}}$ & $78.46^{\mathrm{a}}$ & 2.39 \\
Tyrosine & $71.53^{\mathrm{c}}$ & $73.50^{\mathrm{bc}}$ & $60.69^{\mathrm{d}}$ & $78.33^{\mathrm{ab}}$ & $80.40^{\mathrm{a}}$ & 2.65 \\
Valine & $77.18^{\mathrm{ab}}$ & $4.44^{\mathrm{b}}$ & $59.30^{\mathrm{c}}$ & $79.10^{\mathrm{a}}$ & $79.86^{\mathrm{a}}$ & 1.46 \\
\hline
\end{tabular}

Means within lines followed by different letters statically differ by Tukey test at $5 \%$ of probability.

Source: Elaboration of the authors.

Among the essential amino acids, arginine presented higher $\mathrm{ADC}$, corroborating the results obtained for Nile tilapia by Santos et al. (2010), who studied forage radish bran; Freire, Barros and Pezzato (2005) using low tannin sorghum and Ribeiro et al. (2011) for soybean bran, corn gluten and fishmeal. Cultivars orelha de onça, miúda, IPA 20 and comum presented higher $(\mathrm{P}<0.05)$ arginine $\mathrm{ADC}$ in relation to the cultivar gigante.

The lower $(\mathrm{P}<0.05)$ ADCs for histidine, methionine was observed for the gigante cultivar, being in average $32.9 \%$ lower when compared to the other cultivars. ADC values of methionine of cultivars with higher values (orelha de onça, miúda, IPA 20 and comum) were higher than the
ADC obtained for corn (76.3\%) (GUIMARÃES; PEZZATO; BARROS, 2008) and wheat (74.2\%) (FURUYA et al., 2001) and lower than wheat bran ADC (86.7\%) (GONÇALVES et al., 2007) for Nile tilapia. Despite the low methionine content presented by the palm cultivars studied, this amino acid presented high ADC, with exception for the cultivar gigante. According to Guimarães, Pezzato and Barros (2008) this is an indication that amino acids excess or imbalance not always reduces its bioavailability.

Digestibility values of amino acids lysine, threonine and isoleucine were, on average, 31.7\% higher for cultivars orelha de onça, IPA 20 and comum, in comparison with cultivar gigante. The 
cultivar miúda presented intermediary values. Values found for lysine ADC in this study were lower than those found by Furuya et al. (2001), Gonçalves et al. (2007) and Guimarães, Pezzato and Barros (2008) who evaluated soybean bran, gluten bran and cotton bran, respectively. When compared to energetic feeds, lysine ADCs for the cultivars with the higher values (orelha de onça, miúda, IPA 20 and comum) were higher than those found by Guimarães, Pezzato and Barros (2008) for corn meal, wheat bran, rice bran and sorghum.

Cultivars orelha de onça, miúda, IPA 20 and comum presented the highest ADCs $(\mathrm{P}<0.05)$ for leucine and valine, being, on average, $30.2 \%$ higher than the value observed for gigante. Values obtained for valine ADC were higher than those obtained for wheat bran (69.9\%) and lower than soybean bran $(89.4 \%)$ by Furuya et al. (2001).

Among nonessential amino acids, cysteine and asparagine presented higher $\mathrm{ADC}(\mathrm{P}<0.05)$ for the cultivars orelha de onça, miúda, IPA 20 and comum compared to the cultivar gigante. Amino acids glutamine, alanine, glycine and serine, found in the bran of palm cultivars, were more digestible in orelha de onça, comum and IPA 20, and less digestible in gigante and miúda. Tyrosine amino acid ADC was similar to cultivars IPA 20 and comum, followed by miúda and orelha de onça; cultivar gigante presented the worst tyrosine digestibility.

The differences between the ADCs obtained for essential and nonessential amino acids in this study may be related to the tannin level present in the palm bran cultivars assessed. According to MuellerHarvey and Mcallan (1992), tannin can exert a sequestering action on amino acids. This action can be observed in a study by Freire, Barros and Pezzato (2005), who evaluated low sorghum high tannin amino acids ADC do for Nile tilapia, obtaining higher ADC values for cultivars with lower tannin level.
Although Kleemann, Barros and Pezzato (2009) claim that crude protein $\mathrm{ADC}$ does not reflect most amino acids ADC, this study observed the same trend, as the cultivar gigante that presented the lowest protein ADC also presented the lowest amino acids $\mathrm{ADC}$ values.

\section{Conclusion}

Nile tilapia has limitation on the digestibility of dry matter, gross energy, crude protein and amino acids of the cultivars of forage palm IPA 20, miúda, gigante, comum and orelha de onça.

\section{Acknowledgments}

The authors thank CNPq (INCT-CA), CAPES (PROCAD and PRODOC), Ajinomoto, Fazenda Baixa Alegre and Fazenda Aguavale for financing and supporting this research project.

The project was approved by the bioethics committee and was conducted according to technical standards for biosafety and ethics, protocol 12/2010.

\section{References}

AHMAD, M. H.; ABDEL-TAWWAB, M. The use of caraway seed meal as a feed additive in fish diets: Growth performance, feed utilization, and whole-body composition of Nile tilapia, Oreochromis niloticus (L.) fingerlings. Aquaculture, Amsterdam, v. 314, n. 1-4, p. 110-114, 2011.

ASSOCIATION OF OFFICIAL ANALYTICAL CHEMISTRY - AOAC. Official methods of analysis. 17 ed. Arlington: AOAC, 2000. 1018 p.

BIUDES, J. F. V.; PEZZATO, L. E.; CAMARGO, A. F. M. Digestibilidade aparente da farinha de aguapé em tilápias-do-nilo. Revista Brasileira de Zootecnia, Viçosa, v. 38, n. 11, p. 2079-2085, 2009.

BOMFIM, M. A.; LANNA, E. A. T.; DONZELE, J. L.; ABREU, M. L. T.; RIBEIRO, F. B.; QUADROS, M. Redução de proteína bruta com suplementação de aminoácidos, com base no conceito de proteína ideal, em dietas para tilápias do Nilo (Oreochromis niloticus). Revista Brasileira de Zootecnia, Viçosa, v. 37, n. 10, p. 1713-1720, 2008. 
BRAGA, L. G. T.; RODRIGUES, F. L.; AZEVEDO, R. V.; CARVALHO, J .S. O.; RAMOS, A. P. S. Digestibilidade aparente da energia e nutrientes de coprodutos agroindustriais para tilápia do Nilo. Revista Brasileira de Saúde e Produção Animal, Salvador, v. 11, n. 4, p. 1127-1136, 2010.

CARDADOR-MARTÍNEZ1, A.; JIMÉNEZMARTÍNEZ, C.; SANDOVAL, G. Revalorization of cactus pear (Opuntia spp.) wastes as a source of antioxidants. Ciência e Tecnologia de Alimentos, Campinas, v. 31, n. 3, p. 782-788, 2011.

CAVALHEIRO, J. M. O.; SOUZA, E. O.; BORA, P. S. Utilization of shrimp industry waste in the formulation of tilapia (Oreochromis niloticus, Linnaeus) feed. Bioresource Technology, Miramar, v. 98, n. 3, p. 602606, 2007.

FREIRE, E. S.; BARROS, M. M.; PEZZATO, L. E. Coeficiente de digestibilidade aparente e valores de aminoácidos digestíveis do sorgo baixo e alto tanino pela tilápia do Nilo. Veterinária e Zootecnia, Botucatu, v. 12, n. 1, p. 77-88, 2005.

FURUYA, W. M.; PEZZATO, L. E.; BARROS, M. M.; BOSCOLO, W. R.; CYRINO, J. E. P.; FURUYA, V. R. B.; FEIDEN, F. Tabelas brasileiras para a nutrição de tilápias. Toledo: GFM Gráfica \& Editora, 2010. 100 p.

FURUYA, W. M.; PEZZATO, L. E.; PEZZATO, A. C.; BARROS, M. M.; MIRANDA, E. C. Coeficientes de digestibilidade e valores de aminoácidos digestíveis de alguns ingredientes para tilápia do Nilo. Revista Brasileira de Zootecnia, Viçosa, v. 30, n. 4, p. 11431149, 2001.

GONÇALVES, G. S.; PEZZATO, L. E.; PADILHA, P. M.; BARROS, M. M. Disponibilidade de fósforo em alimentos vegetais e suplementação da enzima fitase para tilápia do Nilo (Oreochromis niloticus). Revista Brasileira de Zootecnia, Viçosa, v. 36, n. 5, p. 14731480, 2007.

GUIMARÃES, I. G.; PEZZATO, L. E.; BARROS, M. M. Amino Acid availability and protein digestibility of several protein source for Nile tilapia, Oreochromis niloticus. Aquaculture Nutrition, Oxford, v. 14, n. 5, p. 396-404, 2008.

HILTON, J. W.; ATKINSON, J. L.; SLINGER, S. J. Effect of increased dietary fiber on the growth of rainbow trout (Salmogairdinerri). Canadian Journal of Fisheries and Aquatic Sciences, v. 40, n. 1, p. 81-85, 1983.
JUSTI, K. C.; PADRE, R. G.; HAYASHI, C.; SOARES, C. M.; VISENTAINER, J. V.; SOUZA, N. E.; MATSUSHITA, M. Efeito da temperatura da água sobre desempenho e perfil de ácidos graxos de tilápia do Nilo (Oreochromis niloticus). Acta Scientiarum. Animal Sciences, Maringá, v. 27, n. 4, p. 529-534, 2005.

KLEEMANN, G. K.; BARROS, M. M.; PEZZATO, L. E. Valor nutricional do farelo de algodão para a tilápia do Nilo (Oreochromis niloticus). Acta Scientiarum Animal Sciences, Maringá, v. 31, n. 1, p. 87-94, 2009.

KÖPRÜCÜ, K.; ÖZDEMIR, Y. Apparent digestibility of selected feed ingredients for Nile tilapia (Oreochromis niloticus). Aquaculture, Amsterdam, v. 250, n. 1-2, p. 308-316, 2005.

LANNA, E. A. T.; PEZZATO, L. E.; CECON, P. R.; FURUYA, W. M.; BOMFIM, M. A. D. Digestibilidade aparente e trânsito gastrintestinal em tilápia do Nilo (Oreochromis niloticus), em função da fibra bruta da dieta. Revista Brasileira de Zootecnia, Viçosa, v. 33, n. 6, p. 2186-2192, 2004. Suplemento 3.

LIMA, M. R.; LUDKE, M. C. M.; PORTO NETO, F. F.; PINTO, B. W. C.; TORRES, T. R.; SOUZA, E. J. O. Farelo de resíduo de manga para tilápia do Nilo. Acta Scientiarum. Animal Sciences, Maringá, v. 33, n. 1, p. 65-71, 2011.

MEURER, F.; HAYASHI, C.; BOSCOLO, W. R.; SOARES, C. M. Lipídeos na alimentação de alevinos revertidos de tilápia do Nilo (Oreochromis niloticus L.). Revista Brasileira de Zootecnia, Viçosa, v. 31, n. 2, p. 566-573, 2002.

MINISTÉRIO DA PESCA E AQUICULTURA - MPA. Boletim estatístico da pesca e aquicultura 2010. Brasília, DF, 2012. 129 p.

MUELLER-HARVEY, I.; McALLAN, A. B. Tannins: Their biochemistry and nutritional properties. In: Morrison, I. M. (Ed.). Advances in Plant Cell Biochemistry and Biotechnology. JAI Press Ltd., London, 1992, p. 152-217.

NOSE, T. On the digestion of food protein by gold-fish (Carassius auratus L.) and rainbow trout (Salmoirideus G.). Bulletin Freshwater Fish Research Laboratory, Tokyo, v. 10, p. 11-12, 1960.

PEZZATO, L. E.; MIRANDA, E. C.; BARROS, M. M.; FURUYA, W. M.; PINTO, L. G. Q. Digestibilidade aparente da matéria seca e da proteína bruta e a energia digestível de alguns alimentos alternativos pela tilápia do Nilo (Oreochromis niloticus). Acta Scientiarum. Animal Sciences, Maringá, v. 26, n. 3, p. 329-337, 2004. 
PEZZATO, L. E; MIRANDA, E. C.; BARROS, M. M.; PINTO, L. G. Q.; FURUYA, W. M.; PEZZATO, A. C. Digestibilidade aparente de ingredientes pela tilápia do Nilo (Oreochromis niloticus). Revista Brasileira de Zootecnia, Viçosa, v. 31, n. 4, p. 1595-1604, 2002.

PEZZATO, L. E.; MIRANDA, E. C.; BARROS, M. M.; PINTO, L. G. Q.; FURUYA, W. M.; PEZZATO, A. C. Digestibilidade aparente de ingredientes pela tilápia do Nilo (Oreochromis niloticus). Revista Brasileira de Zootecnia, Viçosa, v. 31, n. 4, p. 1595-1604, 2002.

PINTO, L. G. Q.; PEZZATO, L. E.; MIRANDA, E. C.; BARROS, M. B.; FURUYA, W. M. Ação do tanino na digestibilidade de dietas pela tilápia do Nilo (Oreochromis niloticus). Acta Scientiarum. Animal Sciences, Maringá, v. 22, n. 3, p. 671-681, 2000.

PORTZ, L.; CYRINO, J. E. P. Digestibility of nutrients and amino acids of different protein sources in practical diets by lagermoth bass Micropterus salmoides (Lacepéde, 1802). Aquaculture Research, Oxford, v. 35, p. $312-320,2004$.

RIBEIRO, F. B.; LANNA, E. A. T.; BOMFIM, M. A. D.; DONZEÇE, J. L.; QUADROS, M.; CUNHA, P. S. L. True and apparent digestibility of protein and amino acids of feed in Nile tilapia. Revista Brasileira de Zootecnia, Viçosa, MG, v. 40, n. 5, p. 939-946, 2011.

RICHTER, N.; SIDDHURAJU, P.; BECKER, K. Evaluation of nutritional quality of moringa (Moringa oleifera Lam.) leaves as an alternative protein source for Nile tilapia (Oreochromis niloticus L.). Aquaculture, Amsterdam, v. 217, n. 1-4, p. 599-611, 2003.
SANTOS, E. L.; LUDKE, M. C. M. M.; BARBOSA, J. M.; RABELLO, C. B. V.; LUDKE, J. V.; WINTERLE, W. M. C.; SILVA, E. G. Níveis de farelo de coco em rações para alevinos de tilápia do Nilo. Revista Brasileira de Saúde e Produção Animal, Salvador, v. 10, n. 2, p. 390-397, 2009.

SANTOS, V. G.; FERNANDES JUNIOR, A. C.; KOCH, J. F. A.; BARROS, M. M.; GUIMARÃES, I. G.; PEZZATO, L. E. Composição química e digestibilidade do farelo de nabo forrageiro para Tilápia do Nilo. Revista Brasileira de Saúde e Produção Animal, Salvador, v. 11, n. 2, p. 537-546, 2010.

SHIAU, S. Y. Utilization of carbohydrates in warmwater fish-with particular reference to tilapia, Oreochromis niloticus X O. aureus. Aquaculture, Amsterdam, v. 151, n. 1-4, p. 79-96, 1997.

SILVA, L. C. R.; FURUYA, W. M.; SANTOS, L. D.; SANTOS, V. G.; SILVA, T. S. C.; PINSETTA, P. J. Níveis de treonina em rações para tilápias-do-nilo. Revista Brasileira de Zootecnia, Viçosa, v. 35, n. 4, p. 1258-1264, 2006.

TACHIBANA, L.; GONÇALVES, G. S.; GUIMARAES, I. G.; PEZZATO, L. E. Digestibilidade aparente do triticale para a tilápia-do-nilo. Boletim do Instituto de Pesca, São Paulo, v. 36, n. 1, p. 39-44, 2010.

TACON, A. G. J.; METIAN, M. Global overview on the use of fish meal and fish oil in industrially compounded aquafeeds: trends and future prospects. Aquaculture, Amsterdam, v. 285, n. 1-4, p. 146-158, 2008. 